\title{
Raising the Efficiency of some Ornamental Plants to Get Rid of Formaldehyde
}

\author{
Koriesh, E. M ${ }^{1}$; Eman. I. Moghazy ${ }^{1}$; Asmaa. M. Abdel Salam ${ }^{1}$ and A. Abd El-Mo'omen ${ }^{2}$ \\ ${ }^{1}$ Hortculture Department, Faculty of Agriculture, Suez Canal University, Ismailia-41522, Egypt \\ ${ }^{2}$ Chemistry Department, Faculty of Science, Suez Canal University, Ismailia, Egypt
}

Received: $26 / 3 / 2018$

\begin{abstract}
Two experiments were carried out in the Horticulture Department, Faculty of Agriculture, Suez Canal University on Schefflera, Dodonaea and Cordyline plants during the successive seasons from 2014 to 2017 . The objective was to study the effect of nitrogen fertilization at 100, 150 and $200 \mathrm{ppm}$ interacted with magnesium at 50,75 and $100 \mathrm{ppm}$ with other nutrients on increasing the efficiency of plants to reduce pollutants and raising efficiency in reducing formaldehyde from closed chamber. The results showed that the best treatments were the plants fertilized with $200 \mathrm{ppm} \mathrm{N}$ and $75 \mathrm{ppm} \mathrm{Mg}$ for formaldehyde reduction using by Schefflera actinophylla, Cordyline terminalis and Dodonaea viscosa. The rate of reduction in these treatments over control ranged from 350\%-725\% for Schefflera, 275\%-630\% for Cordyline and 300\%-400\% for Dodonaea, respectively.
\end{abstract}

Keywords: Formaldehyde, air pollution, fertilization.

\section{INTRODUCTION}

Formaldehyde is a well-known cross-linking agent that can inactivate, stabilize, or immobilize proteins (Metz et al., 2004). Wolverton's research showed that the levels of formaldehyde were reduced from potentially toxic levels of $0.18 \mathrm{ppm}$ to $0.03 \mathrm{ppm}$, within the safety limits defined by the World Health Organization (Wolverton, 1996). Formaldehyde is a ubiquitous chemical found in virtually all indoor environments. The major sources, which have been reported and publicized, include urea-formaldehyde foam insulation (UFFI) and particle board or pressedwood products. Consumer paper products, including grocery bags, waxed papers, facial tissues, and paper towels, are treated with urea formaldehyde (UF) resins. Many common household cleaning agents contain Formaldehyde. UF resins are used as stiffeners, wrinkle resisters, water repellants, fire retardants, and adhesive binders in floor covering, carpet backing, and permanent-press clothes. Formaldehyde irritates the mucous membranes of the eyes, nose, and throat. It is a highly reactive chemical that combines with protein and can cause allergic contact dermatitis. The most widely reported symptoms from exposure to high levels of this chemical include irritation of the upper respiratory tract and eyes and headaches. Until recently, the most serious disease attributed to Formaldehyde exposure was asthma (WHO, 2010).

$\mathrm{Xu}$ et al. (2011) used three potted plants (Chlorphytum comosum, Aloe vera and Epipremnum aureum) to remove formaldehyde from indoor air chambers. They found that the formaldehyde-removal capacity of the plants depended on the dehydrogenase activity in the leaves and root system - that is, how efficiently the plant could metabolize formaldehyde. As Wolverton found earlier, these investigators also found that formaldehyde removal by plants was diffusionlimited. That means increasing the circulation of contaminated air through the root system and leaves improved the formaldehyde-removal effect.

Yang et al. (2009) concluded that plants can remove volatile organic compounds (VOCs) (formaldehyde belongs to VOCs) from indoor air by different methods including stomatal uptake, absorption, and adsorption to plant surfaces.

Organization and Unaids (2006) recommended a limit of indoor HCHO of $0.08 \mathrm{ppm}$. Gases were released up to the initial concentration, and then monitoring of data was started until the mean concentration dropped to the indoor air quality management acts (IAQMA) standard.

Dose of $\mathrm{HCHO}$ was $2 \mathrm{ppm}$ in this study. The $\mathrm{HCHO}$ measurement started when its concentration exceeded 2 ppm. Aydogan and Montoya (2011) adopted an initial concentration of $1.63 \mathrm{ppm} \mathrm{HCHO}$ in their experiment.

The air inside a home, office, or public building is the subject of much interest and is referred to as indoor air pollution or indoor air quality (IAQ). These interior spaces may be contaminated by formaldehyde, and other products emanating from building materials; and by other pollutant sources indoors. (Vallero and Brasier, 2008).

A more benign addition to air filtration could be the use of plants (Reshma et al., 2017). In addition to basic photosynthesis that removes carbon dioxide and returns oxygen to the air, plants can remove toxicants from air, soil, and water in at least two ways.

$\Rightarrow$ First, they can metabolize some toxic chemicals, releasing harmless by-products, and

$\Rightarrow$ second, they can incorporate toxicants such as heavy metals into plant tissues, thus sequestering them (Claudio, 2011).

An expedition launched from about three decades by Wolverton et al. (1989) as a first step in reducing indoor air pollution or to reduce off-gassing from building materials and human activities. In Egypt and through the last two decades many indoor spaces, either living of working areas have different air condition systems. This allowed air pollution problems associated with sealed space. Besides, the increasing transportation increased the outdoor air pollution. It is well known that plants working as air pollutant sinks.

Shefflera actinophylla (Endl.) Harms umbrella tree, octopus tree is a large genus with over 650 species 
of polygamous or dioecious trees, tall shrubs or climbers distributed in tropical and subtropical regions (Sabulal et al., 2008).

Dodonaea viscosa Linn. Isa shrub of blooming plant in the soapberry family, Sapindaceae that has cosmopolitan distribution. Cordyline terminalis (L.) Kunth (ti plant; ti; green ti) Leaf clusters are arranged in close spirals at the branch tips (Kobayashi et al., 2007).

From all metabolic elements which plants use, nitrogen needs in the largest amounts. Nitrogen $(\mathrm{N})$ increases leaf quality, it is an integral part of chlorophyll manufacture through photosynthesis, where plants utilize light to convert atmospheric carbon dioxide into carbohydrates (Tucker, 2004). Understanding the processes that govern $\mathrm{N}$ uptake and distribution in plants is of major importance with respect to both environmental concerns and the plant quality.

Chlorophyll content is approximately proportional to leaf nitrogen content (Bojović and Marković, 2009). Therefore, photosynthetic pigments are integral parts of photosynthetic processes and widely used to assess the relative impact of environmental stresses on the photosynthetic properties (Tsygankov et al., 2017 ).

Different studies have revealed that the total chlorophyll of leaves increased as the $\mathrm{N}$ supply increases (Mascarello et al., 2016; Schliemann et al., 2016; Jin et al., 2015) .

Magnesium is an essential plant nutrient. It has a wide range of key roles in many plant functions. One of the magnesium's well-known roles is in the photosynthesis process, maintenance of enzyme activities such as of $\mathrm{H}^{+}$ATPase, kinases and polymerases (Guo et al., 2016). As it is a building block of the chlorophyll, which makes leaves appear green. Magnesium deficiency might be a significant limiting factor in plant production. It is a constituent fundamental of the chlorophyll molecule, which is the driving active force of photosynthesis (Fiedor et al., 2008).

It is also essential important for the metabolism of sugars. Also, it is an enzyme catalyst activator in the synthesis of DNAs and RNAs. Magnesium regulates coordinate uptake of the other required elements, serves as a carrier transporter of phosphate compounds throughout in the plant, facilitates promote the translocation of carbohydrates sugars and starches (Tucker, 2004).

So, through this work, we are looking to increase the efficiency of two indoor plants (Schefflera actinophylla (Endl.) Harms, Cordyline terminalis (L.) Kunth) and one outdoor plant belongs to C4 plants (Dodonaea viscosa (L.) Jacq) for reducing formaldehyde from a closed chamber. Creation of a new fertilization program to increase the air pollution tolerance index of plants.

\section{MATERIALS AND METHODS}

This experiment was conducted on about 2 years old Schefflera actinophylla (Endl.) Harms, Cordyline terminalis (L.) Kunth and Dodonaea viscosa (L.) Jacq plants. The aim of this experiment was to find out the individual and combined effects of different levels of nitrogen and magnesium on some vegetative characters and some chemical components.

All treatments received $\mathrm{P}, \mathrm{K}$ and $\mathrm{Ca}$ as 60,280 and $280 \mathrm{ppm}$, respectively, and trace elements as recommended by Marken et al. (2010).

For Schefflera, rooted cuttings plants, about 20-25 $\mathrm{cm}$ long, were planted in $20 \mathrm{cms}$ pots filled with a mixture of peat-moos, sand and clay at the proportion of 1: 1: 1 by volume in both seasons. Uniformly plants were selected for the experiments.

For Cordyline, rooted terminal cutting of about 14$15 \mathrm{~cm}$ long and having 7-8 leaves were selected. One transplant was planted in $20 \mathrm{~cm}$ plastic pots that contained the same mentioned medium.

Concerning Dodonaea, plants produced from seeds and transplants were taken from the nursery of the Faculty of Agriculture, Suez Canal University. It was about $55-60 \mathrm{~cm}$ height and planted in $25 \mathrm{~cm}$ plastic pots.

The following measurements were recorded: Plant height $(\mathrm{cms})$, Main stem diameter $(\mathrm{mm})$ and Number of leaves.

\section{Gases exposure and monitoring}

Individual treated plants were placed in a growth chamber. It is a $250 \mathrm{~L}$ gas-light test handmade chamber covered with 100 micron plastic sheets. The growth chamber exposed to about 10 fold normal pollutant concentrations as 2-5 ppm of HCHO (formaldehyde).

Plants were individually placed in the chamber, and then injected with $\mathrm{HCHO}$. For formaldehyde, plants were left in the chambers for 24 hours. An empty chamber was injected with each pollutant and left without plants as a control. The gas concentration within the chamber was determined after $24 \mathrm{~h}$ and compared with the control by SM207 Portable Formaldehyde $\mathrm{CH} 2 \mathrm{O}$ Tester Hygrometer. HCHO monitor (Formaldehyde meter htV; PPM Technology Ltd., Caernarfon, UK), temperature and humidity monitor (iLog; Escort, Cryopak, TCP Company, Edison, NJ, USA), and SC-

A 60's cms fluorescent bulb installed, the illumination of the lamp was (3000) lux approximately $(3000 \mathrm{x}$ factor 0.013 for fluorescent tube $=$ $\left.39 \mu \mathrm{mol} \cdot \mathrm{m}^{-2} \mathrm{~s}^{-1}\right)$.

A small computer fan was placed inside the growth room to ensure even dispersal of the $\mathrm{HCHO}$ gas, to produce complete disperse of the gas in the space.

The IBM SPSS statistical software was used to analyze the experimental data (Green and Salkind, 2016).

\section{RESULTS}

\section{Plant height:}

Although there were significant differences in the main effects of nitrate $\mathrm{N}$ levels regardless of $\mathrm{Mg}$ fertilization as well as $\mathrm{Mg}$ levels regardless of nitrate $\mathrm{N}$ fertilization, these results are misleading (Table 1). 
From this Table it can, in general, say that plants fertilized with $200 \mathrm{ppm}$ of nitrogen, regardless of $\mathrm{Mg}$ showed the tallest plants for the three studied species during both seasons.

In general, fertilizing plants with either 75 or 100 ppm of $\mathrm{Mg}$, regardless of nitrogen levels, produced the tallest plants during both seasons.

\section{Stem diameter $(\mathbf{m m})$ :}

Concerning the interaction or the first order interaction between the main groups of treatments, data in Table (2) indicate that the stem diameter of the Schefflera plant responded to the fertilization during both seasons at a fertilizing rate of $200 \mathrm{ppm}$ of nitrate $\mathrm{N}$ and $75 \mathrm{ppm}$ of $\mathrm{Mg}$.
Concerning the second plant (Cordyline) the results differed between the first and the second season, and the highest value in the first season originated from plants fertilized with $100 \mathrm{ppm}$ of nitrate $\mathrm{N}$ and $100 \mathrm{ppm}$ of $\mathrm{Mg}$, while in the second season, the best results were for that fertilized with $200 \mathrm{ppm}$ of nitrate $\mathrm{N}$ and $75 \mathrm{ppm}$ of $\mathrm{Mg}$.

In Dodonaea it was clear that more than one fertilizing treatment showed higher values of stem diameter, from these treatments, fertilizing plants with $150 \mathrm{ppm}$ of nitrate $\mathrm{N}$ and either 75 or $100 \mathrm{ppm}$ of $\mathrm{Mg}$ or $100 \mathrm{ppm}$ of nitrate $\mathrm{N}$ with either 50 or $100 \mathrm{ppm}$ of $\mathrm{Mg}$ without significant differences between both seasons.

Table (1): Main effects of nitrogen fertilization as nitrate and magnesium on plant height $(\mathrm{cm})$ of the studied plants during 2014 and 2015 seasons

\begin{tabular}{|c|c|c|c|c|c|c|}
\hline \multirow{2}{*}{ Fertilizer } & \multicolumn{2}{|c|}{ Schefflera } & \multicolumn{2}{|c|}{ Cordyline } & \multicolumn{2}{|c|}{ Dodonaea } \\
\hline & 2014 & 2015 & 2014 & 2015 & 2014 & 2015 \\
\hline 0 nitrate $\mathbf{N}$ (with $\mathrm{P}, \mathrm{K}, \mathrm{Ca}, \mathrm{S}$ and TE) & 38.8 & 54.0 & 21.2 & 21.2 & 47.7 & 44.3 \\
\hline 100 nitrate $N$ (with $P, K, C a, S$ and TE) & 40.0 & 66.7 & 31.4 & 30.0 & 80.2 & 60.6 \\
\hline 150 nitrate $N$ (with $P, K, C a, S$ and TE) & 38.8 & 63.5 & 30.2 & 65.5 & 82.6 & 65.2 \\
\hline 200 nitrate $N$ (with $P, K, C a, S$ and TE) & 53.0 & 64.3 & 36.8 & 60.8 & 73.0 & 59.7 \\
\hline LSD first main 0.05 & 6.3 & 5.1 & 5.1 & 5.1 & 5.5 & 10.0 \\
\hline $0 \mathrm{Mg}$ (with P, K, Ca, S and TE) & 47.7 & 48.7 & 20.3 & 42.6 & 55.8 & 53.6 \\
\hline $50 \mathrm{Mg}$ (with P, K, Ca, S and TE) & 35.3 & 67.9 & 40.1 & 35.2 & 75.7 & 65.7 \\
\hline $75 \mathrm{Mg}$ (with P, K, Ca, S and TE) & 43.6 & 65.0 & 28.0 & 47.9 & 75.7 & 58.1 \\
\hline $100 \mathrm{Mg}$ (with P, K, Ca, S and TE) & 43.9 & 66.9 & 31.1 & 51.8 & 76.2 & 52.4 \\
\hline LSD second main 0.05 & 6.3 & 5.13 & 5.1 & 5.1 & 5.5 & 10.04 \\
\hline
\end{tabular}

\section{Number of leaves:}

Concerning the interaction or the first order of the interaction between the main groups of treatments, data in Table (3) indicate that the leaf number of Schefflera plant responded to the fertilization during both seasons at the rate of $200 \mathrm{ppm}$ of nitrate $\mathrm{N}$ and $75 \mathrm{ppm}$ of $\mathrm{Mg}$, however, it was not the largest value.

In the second plant Cordyline, the results differed between the first and the second seasons, and the best values in the first season came from plants fertilized with $200 \mathrm{ppm}$ of nitrate $\mathrm{N}$ and $100 \mathrm{ppm}$ of $\mathrm{Mg}$, while in the second season, the best treatment was that fertilized with $150 \mathrm{ppm}$ of nitrate $\mathrm{N}$ and $100 \mathrm{ppm}$ of $\mathrm{Mg}$.

In the third plant, Dodonaea showed that a fertilizer treatment showed higher values of leaf number, from these treatments, fertilizing plants with $100 \mathrm{ppm}$ of nitrate $\mathrm{N}$ and either $50 \mathrm{ppm}$ of $\mathrm{Mg}$ without significant differences during both seasons.
Data of the pollution experiments are presented as figures. Some data were transformed using transformations according to McDonald (2014), single replicate (Zaiontz, 2013; Gomez and Gomez, 1984).

The recorded results indicated that the response of the three plants, Schefflera, Cordyline and Dodonaea, was not similar in their absorption of formaldehyde by the effect of plant fertilization with $\mathrm{N}$ and $\mathrm{Mg}$ fertilizers.

Concerning Schefflera plants (Table 4and Figure $1)$, the best three fertilizer treatments containing 150 , 200 and $100 \mathrm{ppm}$ of $\mathrm{N}$ with 100, 75 and $50 \mathrm{ppm}$ of $\mathrm{Mg}$, respectively. In the Cordyline (Table 4and Figure 1) the best treatments were fertilizer containing 200,150 and 200 of $\mathrm{N}$ with 75, 100 and $200 \mathrm{ppm}$ of $\mathrm{Mg}$, respectively.

In Dodonaea plant, the superiority of the treatments that used to be fertilizer containing 100, 200 and 150 of $\mathrm{N}$ and 100,75 and 0 of $\mathrm{Mg}$, respectively. 
Table (2): Effect of the interaction between nitrogen fertilization as nitrate and magnesium on stem diameter (mm) of the studied plants during 2014 and 2015 seasons

\begin{tabular}{|c|c|c|c|c|c|c|c|}
\hline \multicolumn{2}{|l|}{ Fertilizer } & \multicolumn{2}{|c|}{ Schefflera } & \multicolumn{2}{|c|}{ Cordyline } & \multicolumn{2}{|c|}{ Dodonaea } \\
\hline Nitrogen & Magnesium & 2014 & 2015 & 2014 & 2015 & 2014 & 2015 \\
\hline 0 & 0 & 9.40 & 9.75 & 4.10 & 4.11 & 5.47 & 4.64 \\
\hline 0 & 50 & 10.6 & 10.3 & 3.90 & 3.97 & 4.75 & 4.92 \\
\hline 0 & 75 & 9.10 & 9.66 & 3.20 & 3.23 & 3.68 & 3.51 \\
\hline 0 & 100 & 8.20 & 8.19 & 4.00 & 4.07 & 3.07 & 3.61 \\
\hline 100 & 0 & 10.6 & 11.5 & 3.70 & 3.74 & 4.05 & 4.49 \\
\hline 100 & 50 & 9.50 & 9.12 & 9.20 & 3.49 & 8.93 & 4.08 \\
\hline 100 & 75 & 7.90 & 10.8 & 8.40 & 3.77 & 7.50 & 5.30 \\
\hline 100 & 100 & 9.10 & 12.5 & 11.3 & 10.21 & 8.53 & 5.29 \\
\hline 150 & 0 & 9.0 & 9.52 & 3.40 & 13.34 & 5.08 & 4.47 \\
\hline 150 & 50 & 10.3 & 12.0 & 8.50 & 11.4 & 9.46 & 3.54 \\
\hline 150 & 75 & 8.90 & 9.44 & 9.00 & 11.07 & 8.80 & 5.21 \\
\hline 150 & 100 & 9.70 & 10.6 & 9.00 & 11.00 & 8.43 & 4.91 \\
\hline 200 & 0 & 9.80 & 9.93 & 3.70 & 10.56 & 3.48 & 2.79 \\
\hline 200 & 50 & 11.4 & 11.6 & 6.80 & 7.96 & 10.5 & 4.42 \\
\hline 200 & 75 & 12.3 & 10.4 & 8.30 & 14.72 & 9.36 & 4.61 \\
\hline 200 & 100 & 14.7 & 10.4 & 7.80 & 11.01 & 9.10 & 3.92 \\
\hline LSD 0.05 & & NS & NS & 2.3 & 2.55 & 2.20 & 1.30 \\
\hline
\end{tabular}

Table (3): Effect of the interaction between nitrogen fertilization as nitrate and magnesium on number of leaves of the studied plants during 2014 and 2015 seasons

\begin{tabular}{|c|c|c|c|c|c|c|c|}
\hline \multicolumn{2}{|l|}{ Fertilizer } & \multicolumn{2}{|c|}{ Schefflera } & \multicolumn{2}{|c|}{ Cordyline } & \multicolumn{2}{|c|}{ Dodonaea } \\
\hline Nitrogen & Magnesium & 2014 & 2015 & 2014 & 2015 & 2014 & 2015 \\
\hline 0 & 0 & 11.0 & 12.3 & 9.3 & 9.3 & 140.6 & 135.3 \\
\hline 0 & 50 & 8.60 & 38.3 & 8.6 & 8.6 & 89.0 & 77.0 \\
\hline 0 & 75 & 9.60 & 28 & 11.3 & 11.3 & 119.0 & 140.6 \\
\hline 0 & 100 & 27.0 & 25 & 8.6 & 8.6 & 37.3 & 45.6 \\
\hline 100 & 0 & 19.3 & 22.6 & 9.0 & 9.0 & 172.0 & 147.0 \\
\hline 100 & 50 & 15.0 & 13.6 & 11.6 & 9.6 & 188.3 & 186.0 \\
\hline 100 & 75 & 11.3 & 19.3 & 11.3 & 15.0 & 170.0 & 108.3 \\
\hline 100 & 100 & 10.6 & 19.6 & 11.3 & 13.3 & 160.0 & 141.6 \\
\hline 150 & 0 & 26.6 & 31.3 & 9.6 & 13.3 & 175.6 & 147.3 \\
\hline 150 & 50 & 14.3 & 19.0 & 11.0 & 16.0 & 166.6 & 171.6 \\
\hline 150 & 75 & 11.3 & 8.66 & 11.6 & 14.3 & 138.3 & 153.3 \\
\hline 150 & 100 & 13.3 & 19.0 & 7.0 & 20.6 & 142.0 & 143.3 \\
\hline 200 & 0 & 33.3 & 32.3 & 15.0 & 15.6 & 65.6 & 59.0 \\
\hline 200 & 50 & 13.3 & 18.3 & 15.6 & 19.3 & 126.6 & 183.3 \\
\hline 200 & 75 & 39.3 & 18.6 & 13.6 & 10.0 & 138.6 & 90.0 \\
\hline 200 & 100 & 29.6 & 17.3 & 19.3 & 15.3 & 146.6 & 136.6 \\
\hline LSD 0.05 & & 10.8 & 10.8 & NS & 6.0 & 43.9 & 75.6 \\
\hline
\end{tabular}


Table (4): Best treatments for Schefflera, Cordyline and Dodonaea as affected by fertilization plants with nitrogen and magnesium in reducing formaldehyde (calculated for $1000 \mathrm{~cm}^{2}$ leaf area)

\begin{tabular}{|c|c|c|c|c|c|}
\hline \multicolumn{2}{|c|}{$\begin{array}{l}\text { Efficiency of Schefflera for } \\
\text { reducing formaldehyde }\end{array}$} & \multicolumn{2}{|c|}{$\begin{array}{l}\text { Efficiency of Cordyline for reducing } \\
\text { formaldehyde }\end{array}$} & \multicolumn{2}{|c|}{$\begin{array}{l}\text { Efficiency of Dodonaea for reducing } \\
\text { formaldehyde }\end{array}$} \\
\hline N150 Mg100 & 2.784 & N $200 \mathrm{Mg} 75$ & 5.697 & N100 Mg100 & 4.009 \\
\hline N $200 \mathrm{Mg} 75$ & 2.005 & N150 Mg100 & 5.572 & N $200 \mathrm{Mg} 75$ & 3.370 \\
\hline N100 Mg50 & 1.166 & N200 Mg100 & 4.618 & N150 Mg0 & 2.477 \\
\hline N0 Mg100 & 0.947 & N100 Mg50 & 3.792 & N0 Mg75 & 1.950 \\
\hline
\end{tabular}

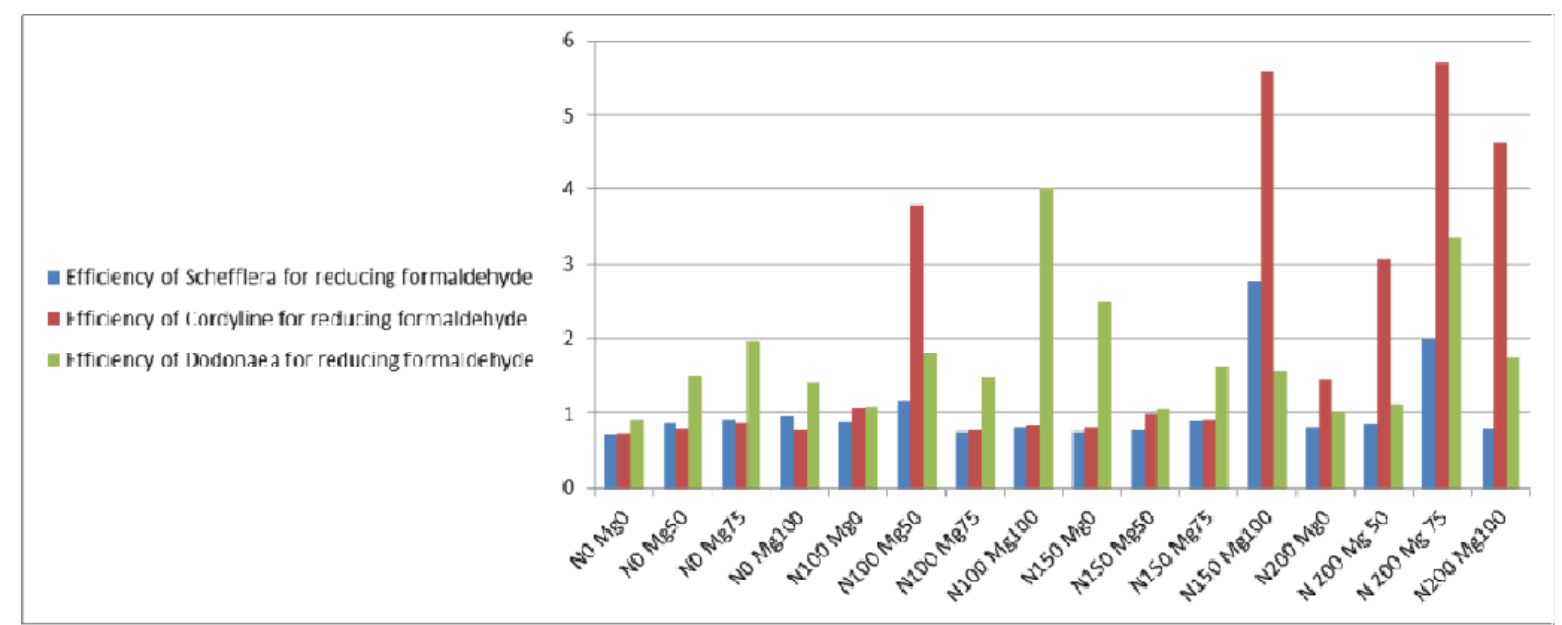

Figure (1): Efficiency of Schefflera, Cordyline and Dodonaea for reducing formaldehyde after 24 hours from injection as affected by fertilizing plants with nitrogen and magnesium (based on transformed data and calculated for $1000 \mathrm{~cm}^{2}$ leaf area)

The present investigation was carried out as a trial to improve the efficiency of some ornamental plants decreasing formaldehyde, as well as, their quality by using certain fertilization programs including some fertilizers. Among the different parameters that determine the tolerance level of plants to pollution, chlorophyll content plays an important role as it indicates the photosynthetic activity (Jyothi and Jaya, 2010).

Tolerance of plants to air pollutants is reported to be linked with high chlorophyll content which related to photosynthesis (Badamasi, 2017).

Photosynthesis is influenced by two categories of factors - external or environmental and internal or plant factors. According to the law of limiting factors, photosynthesis is limited by the most limiting factor. This means that, at any given time, only one factor can be the most limiting factor among all and this factor determines the rate of photosynthesis.

Among nutrients, nitrogen influences the rate of photosynthesis. Reduction in nitrogen supply adversely affects photosynthesis, since as nitrogen forms the basic constituent of chlorophyll. In general, all essential elements also affect the rate of photosynthesis.
Also, several minerals are essential for plant growth. These include $\mathrm{Mg}, \mathrm{Fe}, \mathrm{Cu}, \mathrm{CI}, \mathrm{Mn}$, and $\mathrm{P}$ and are closely associated with reactions of photosynthesis. Also, organic acids are involved in numerous metabolic pathways in all plants. These organic acids play essential roles as photosynthetic intermediates.

\section{DISCUSSION}

Growth characteristics and some chemical components in the leaves were studied to calculate the APTI of the studied plants.

Data obtained in the pollutant estimation did not meet the requirements of the analysis of variance, so it required specific transformation types according to every case. To obtain homogeneity of variance, to improve interpretability, even if no formal statistical analysis or visualization is to be performed and to obtain values more closely correspond to normal distribution. In case of formaldehyde, and to reduce skewness, we used square root transformation according to McDonald (2014).

In the results, there are significant effects for fertilization treatments with nitrogen and magnesium 
Horchani et al. (2010) added that nitrogen is taken up by most of the plant species in the form of nitrate $\left(\mathrm{NO}_{3}\right)$ or ammonium $\left(\mathrm{NH}_{4}\right)$. Compared to nitrate $\left(\mathrm{NO}_{3}{ }^{-}\right)$, cucumber plants grown under $\mathrm{NH}^{4+}$ nutrition showed decreased plant growth, net photosynthetic rate, stomatal conductance, intercellular $\mathrm{CO}_{2}$ level, transpiration rate, maximum photochemical efficiency of photosystem II, and $\mathrm{O}_{2}$-independent alternative electron flux, and increased $\mathrm{O}_{2}$-dependent alternative electron flux (Zhou et al., 2011). The uptake rates are determined mainly by the physiological need of every plant and not so much on whether the source is a cation or an anion. Assimilation of $\mathrm{NO}_{3}^{-}$required energy equivalents up to 20 ATP molecule (adenosine triphosphate) $\mathrm{mol}^{-1} \mathrm{NO}_{3}^{-}$, whereas $\mathrm{NH}^{4+}$ assimilation required only $5 \mathrm{ATP} \mathrm{mol}^{-1} \mathrm{NH}^{4+}$ (Fageria et al., 2010).

Magnesium ions $\left(\mathrm{Mg}^{2+}\right)$ are the second most abundant cations in living plant cells, and they are involved in various functions, including photosynthesis, enzyme catalysis, and nucleic acid synthesis (Tanoi and Kobayashi, 2015).

Magnesium $\left(\mathrm{Mg}^{2+}\right)$ acts as a cofactor for more than 300 enzymes that are involved in a wide range of fundamental biochemical processes (Sun et al., 2017). In this concern Dias et al. (2017) found that both of $\mathrm{Mg}$ concentration and light levels affected gas exchange. The highest $\mathrm{CO}_{2}$ assimilation rate and lowest transpiration were observed with $250 \mathrm{mg} \mathrm{MgL}^{-1}$, indicating that increasing $\mathrm{Mg}$ concentration was the optimal Mg supply.

Its adequate level in the soil is important for plant growth. Data reported by Fageria et al. (2010) showed significant increase in root and shoot dry weight, to increasing $\mathrm{Mg}^{2+}$ concentration. They asses that more than $80 \%$ variability in root and shoot dry weight was due to variation in $\mathrm{Mg}^{2+}$ level in the soil.

This means that application of Mg is necessary for maximizing plants yield. According to Choudhury and Khanif (2001), when magnesium status in soil is low in specific location, nitrogen use efficiency, due to $\mathrm{Mg}$ deficiency in that location will be low. It is necessary to overcome this problem by addition of soluble salts of $\mathrm{Mg}$.

Removal of Indoor carbon dioxide and formaldehyde using indoor plants had been studied by $\mathrm{Su}$ and Lin (2015). They indicated that $\mathrm{CO}_{2}$ and formaldehyde (HCHO) are the most common sources of Indoor pollution; their levels can be reduced by using potted plants. In accordance with our previous study, for this purpose, we used Cordyline, Schefflera and Dodonaea, which are easy to grow indoors and outdoors.

The experimental results showed that the concentration of $\mathrm{HCHO}$ was reduced from $7.25 \mathrm{ppm}$ to the safe level of $0.06 \mathrm{ppm}$ by Schefflera, at an average of $0.120 \mathrm{ppm} \cdot \mathrm{min}^{-1}$; reduced from $31.96 \mathrm{ppm}$ to the safe level of $0.09 \mathrm{ppm}$ by Cordyline and at an average of $0.251 \mathrm{ppm} \cdot \mathrm{min}^{-1}$ in case of fertilization experiment. (Figure 1). Because there are no similar studies, this study is somewhat consistent with what reported by $\mathrm{Su}$ and Lin (2015).
The best fertilization treatments suitable for formaldehyde reduction using Schefflera plant is $\mathrm{N}$ with $\mathrm{Mg}$ at the concentration of $150-200 \mathrm{ppm} \mathrm{N}$ and 75-100 ppm Mg. The rate of reduction in these treatments over control ranged from $350 \%-725 \%$. In Cordyline plant, the concentration of $100-200 \mathrm{ppm} \mathrm{N}$ and $50-100 \mathrm{ppm}$ $\mathrm{Mg}$ reduced the formaldehyde to the value ranging from 275 to $630 \%$. In Dodonaea plant, the concentration of 100 and $200 \mathrm{~N}$ and $75-100 \mathrm{Mg}$, caused areduction rate from 300 to $404 \%$ (Figure, 1)

The ability of plants to remove formaldehyde from sealed experimental chamber is demonstrated in Figure (1).

The screening of different plants as affected by fertilization treatments is shown in Table (4) for the second season.

Plants were subjected to fertilizing treatments with nitrogen with magnesium in some selected levels.

Plants in Table (4) and Figure (1) were exposed to different concentrations of formaldehyde. Although these exposures gave a good indication of which plants might be particularly suited to the removal of formaldehyde, there are far above the levels commonly found in indoor atmosphere.

During these experiments, the only controls used were chambers free of plants to test for loss of formaldehyde from chamber leakage.

Because photosynthesis and metabolic rates affect the efficiency of different plants in their removing of pollutants, plants were subjected to fluorescent light at ((3000) lux approximately (3000 x factor 0.013 for fluorescent tube $\left.=39 \mu \mathrm{mol} \cdot \mathrm{m}^{-2} \mathrm{~s}^{-1}\right)$ level, which assemble to the normal indoor lights. The chemical removal rates might be attributed to this light.

The results showed that the removal efficiency of formaldehyde by the studied plants varied according to the fertilizing system or the chemicals used for spraying plant and the genera. The ability of every indoor plant to remove $\mathrm{HCHO}$ from sealed experimental chambers are demonstrated in Figure (1).

Fertilizer is one of the most important management practices used to determine plant quality, affecting the general plant health. The healthier the plant is, the better the pollution abatement.

The effectiveness of the two $\mathrm{N}$ forms on growth and $\mathrm{N}$ uptake varies according to the type of cultivar and $\mathrm{NH}_{4}+/ \mathrm{NO}_{3}-$ ratio. In some plants, for example, spinach, solutions containing $\mathrm{N}$ entirely as $\mathrm{NH}_{4}+$ or $\mathrm{NO}_{3}-$ have been shown to inhibit plant growth more than solutions containing 25 or $50 \%$ of each $\mathrm{N}$ form (Chai et al., 2014; Wang et al., 2009). Besides, Chai et al. (2014) found that chlorophyll a and b, total chlorophyll, stomatal conductance, initial activity and activation state of Rubisco and net photosynthetic rate in spinach leaves were all reduced by increased $\mathrm{NH}_{4}+\mathrm{N} / \mathrm{NO}_{3}-\mathrm{N}$ ratios.

Plant growth and development have long been known to benefit from the presence of $\mathrm{NO}_{3}$ (Coruzzi and Bush, 2001) . However, despite the fact that $\mathrm{NO}_{3}{ }^{-}$ assimilation consumes more energy than $\mathrm{NH}_{4}^{+}$ 
assimilation, only few species perform well when $\mathrm{NH}_{4}$ is the sole $\mathrm{N}$ source (Petropoulos et al., 2008; Wang and $\mathrm{Li}, 2004)$. In the present study, out of the three plants examined, Dodonaea showed tolerance to the tested air pollutants. Mean time, the other two plants showed varying degrees of sensitive responses when exposed to the studied pollutants. The application of soil drench of nitrogen fertilizers in the two forms, nitrate and ammonia, besides the other major and minor nutrients resulted in increasing efficiency of plants for reducing pollutants. Also, spraying plants with different levels of selected organic acids and amino acids have good responses to air pollutants abatements.

These results are in harmony with those reported by EL-Sadek et al. (2012). (Mate and Deshmukh, 2016; Giri et al., 2013), with polluted and non polluted Azadirachta indica, Nerium oleander, Mangifera indicaand- Dalbergi asissoo who showed a decrease in photosynthetic pigments due to air pollution.

\section{REFERENCES}

Aydogan, A. and L.D. Montoya (2011). Formaldehyde removal by common indoor plant species and various growing media. Atmospheric Environment, 45(16): 2675-2682.

Badamasi, H. (2017). Biomonitoring of Air Pollution Using Plants. MAYFEB Journal of Environmental Science, 2.

Bojović, B. and A. Marković (2009). Correlation between nitrogen and chlorophyll content in wheat (Triticum aestivum L.). Kragujevac Journal of Science, 31: 69-74.

Chai, J., J. Liu, J. Zhou and D. Xing (2014). Mitogenactivated protein kinase 6 regulates NPR1 gene expression and activation during leaf senescence induced by salicylic acid. Journal of Experimental Botany, 65: 6513-6528.

Choudhury, T. and Y. Khanif (2001). Evaluation of effects of nitrogen and magnesium fertilization on rice yield and fertilizer nitrogen efficiency using $15 \mathrm{~N}$ tracer technique. Journal of Plant Nutrition, 24(6): 855-871.

Claudio, L. (2011). Planting Healthier Indoor Air. Environmental Health Perspectives, 119 (10): 426-427.

Dias, K. G. D. L., P. T. G. Guimarães, A. E. F. Neto, H. R. O. D. Silveira and J. J. D. J. Lacerda (2017). Effect of magnesium on gas exchange and photosynthetic efficiency of coffee plants grown under different light levels. Agriculture, 7(10): 1-11.

ELSadek, M., S. Sayaka, E. Fujii, E. Koriesh, E. Moghazy and Y. A. El Fatah (2013). Human emotional and psycho-physiological responses to plant color stimuli. Journal of Food, Agriculture \& Environment, 11: 1584-1591.

Fageria, N. K., V. C. Baligar and C. A. Jones (2010). Growth and Mineral Nutrition of Field Crops. CRC Press. ISBN1439816964, PP 586, $3^{\text {rd }}$ Ed.

Fiedor, L., A. Kania, B. Myśliwa-Kurdziel, L. Orzeł and G. Stochel (2008). Understanding chlorophylls: Central magnesium ion and phytyl as structural determinants. Biochimica et BiophysicaActa (BBA)-Bioenergetics, 1777(12): 1491-1500.

Giri, S., D. Shrivastava, K. Deshmukh and P. Dubey (2013). Effect of air pollution on chlorophyll content of leaves. Current Agriculture Research Journal, 1(2): 93-98.

Gomez, K. A. and A. A. Gomez (1984). Statistical Procedures for Agricultural Research. John Wiley \& Sons.

Green, S. B. and N. J. Salkind (2016). Using SPSS for Windows and Macintosh, Books a la Carte. Pearson.

Guo, W., H. Nazim, Z. Liang and D. Yang (2016). Magnesium deficiency in plants: An urgent problem. The Crop Journal, 4: 83-91.

Horchani, F., R. Hajri and S. Aschi Smiti (2010). Effect of ammonium or nitrate nutrition on photosynthesis, growth, and nitrogen assimilation in tomato plants. Journal of Plant Nutrition and Soil Science, 173 (4): 610-617.

Jin, X., G., Yang, C. Tan and C. Zhao (2015). Effects of nitrogen stress on the photosynthetic $\mathrm{CO}_{2}$ assimilation, chlorophyll fluorescence, and sugar-nitrogen ratio in corn. Scientific reports. 5 Sci Rep. 2015 Apr 1; 5: 9311. doi: $10.1038 /$ srep 09311.

Jyothi, S. J. and D. S. Jaya (2010). Evaluation of air pollution tolerance index of selected plant species along roadsides in Thiruvananthapuram, Kerala. J. Environ. Biol., 31: 379-386.

Kobayashi, K., J. Griffis, A. Kawabata and G. Sako (2007). Hawaiian Ti. Honolulu (HI): University of Hawaii. 14 p. (Ornamentals and Flowers; OF-33). http://scholarspace.manoa.hawaii.edu/handle/1 0125/2954

Marken, B., S. DeJohn and Association, E.o.t.N.G. (2010). Container Gardening For Dummies. John Wiley \& Sons

Mascarello, A. C.; T. R. B. da Silva, B. T. Gouveia, D. Bernardi, D. Secco, R.F. Santos and C. Z. Alves, (2016). Chlorophyll meter reading and total nitrogen content applied as topdressing in parts of the crambe plant. African Journal of Biotechnology, 15: 45-49.

Mate, A. R. and R. R. Deshmukh (2016). Analysis of effects of air pollution on chlorophyll, water, carotenoid and anthocyanin content of tree leaves using spectral indices. Int. J. Eng. Sci, 6: 5465-5474.

McDonald, J. H. (2014). Spearman rank correlation. Handbook of Biological Statistics. (3rd ed.). Sparky House Publishing, Baltimore, Maryland. Retrieved from. http://www.biostathandbook.com/transformatio n.html (26 ${ }^{\text {th }}$ August 2017).

Metz, B., F. Gideon, A. Kersten, P. Hoogerhout, H. Brugghe, H. Timmermans, H. Meiring, W. Hennink, D. Crommelin and W. Jiskoot (2004). Identification of Formaldehyde-induced Modifications in Proteins: reactions with model peptides. J. Biol. Chem. Vol. 279: 6235-6243. 
Organization, W. H. and Unaids (2006). Air Quality Guidelines: Global update 2005. World Health Organization

Petropoulos, S., C. Olympios and H. Passam (2008). The effect of nitrogen fertilization on plant growth and the nitrate content of leaves and roots of parsley in the Mediterranean region. Scientia Horticulturae, 118(3): 255-259.

Reshma, V. S., Prashant Kumar, and G. S. Chaitra (2017). Significant Role of Ornamental Plants as Air Purifiers - Int. J. Curr. Microbiol. App. Sci., 6(8): 2591-2606 http://www.ijcmas.com

Sabulal, B., V. George, N. S. Pradeep and M. Dan (2008). Volatile oils from the root, stem and leaves of Schefflera stellata (Gaertn.) Harms (Araliaceae): Chemical characterization and antimicrobial activity. Journal of Essential Oil Research, 20(1): 79-82.

Schliemann, B., M. Treder, M. Schulze, V. Müller, S. Vasta, B. Zampogna, M. Herbort, C. Kösters, M. J. Raschke and S. Lenschow (2016). Influence of different tibial fixation techniques on initial stability in single-stage anterior cruciate ligament revision with confluent tibial tunnels: A biomechanical laboratory study. Arthroscopy: The Journal of Arthroscopic \& Related Surgery, 32(1): 78-89.

Su, Y.-M. and C. H. Lin (2015). Removal of indoor carbon dioxide and formaldehyde using green walls by bird nest fern. The Horticulture Journal, 84: 69-76.

Sun, Y., R. Yang, L. Li and J. Huang (2017). The magnesium transporter MGT10 is essential for chloroplast development and photosynthesis in Arabidopsis thaliana. Molecular Plant, 10: 1584-1587.

Tsygankov, A. A., S. I. Allakhverdiev and T. Tomo (2017). International conference on "Photosynthesis Research for Sustainability2016". Photosynthesis Research, 131: 227-236.

Tucker, M. (2004). Primary nutrients and plant growth. Essential Plant Nutrients, 126.
Vallero, D. A. and C. Brasier (2008). Sustainable Design: The Science of Sustainability and Green Engineering. John Wiley \& Sons, Inc.

Wang, J., Y. Zhou, C. Zhou, Q. Shen and R. Putheti (2009). Effects of $\mathrm{NH}_{4}+-\mathrm{N} / \mathrm{NO}_{3}-\mathrm{-N}$ ratios on growth, nitrate uptake and organic acid levels of spinach (Spinacia oleracea L.). African Journal of Biotechnology, 8(15):3597-3602

Wang, Z. and S. Li (2004). Effects of nitrogen and phosphorus fertilization on plant growth and nitrate accumulation in vegetables. Journal of Plant Nutrition, 27(3): 539-556.

WHO (2000). The Right to Healthy Indoor Air. European health targets. WHO Regional Office for Europe. $\quad$ PP 1-17. http://www.colinsoskolne.com/documents/E69 828.pdf

WHO (World Health Organisation) (2010). WHO guidelines for indoor air quality: selected pollutants.

Wolverton, B. C. (1996). How to Grow Fresh Air. New York: Penguin Books.

Wolverton, B. C., W. L. Douglas and K. Bounds (1989). A Study of Interior Landscape Plants for Indoor Air Pollution Abatement. National Aeronautics and Space Administration, John C. Stennis Space Centre.

$\mathrm{Xu}, \mathrm{Z}$., L. Wang and H. Hou (2011). Formaldehyde removal by potted plant-soil systems. J. Hazard Mater, 192(1): 314 - 318.

Yang, D., S. Pennisi, K. Son and S. Kays (2009). Screening Indoor Plants for Volatile

Zaiontz, C. (2013). Real Statistics Using Excel. Two Factor ANOVA without Replication. Word Press. http://www.real-statistics.com/two-wayanova/two-factor-anova-without-replication.

Zhou, J., F. Qin, J. Su, J. Liao and H. Xu (2011). Purification of formaldehyde-polluted air by indoor plants of Araceae, Agavaceae and Liliaceae. J Food Agric Environ, 9: 1012-1018.

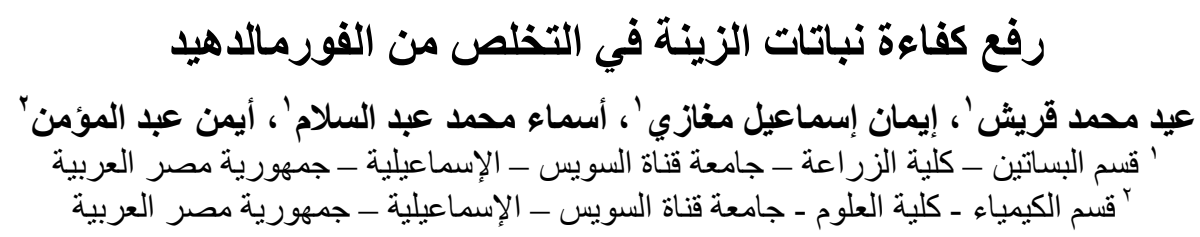

أجريت هذه الار اسة في مشتل ومعامل الزينة بقسم البساتين بكلية الزراعة جامعة قناة السويس بمحافظة الإسماعيلية على نباتات

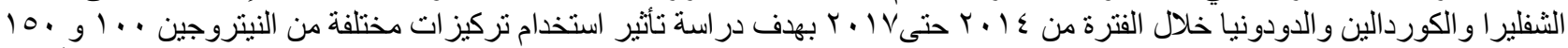

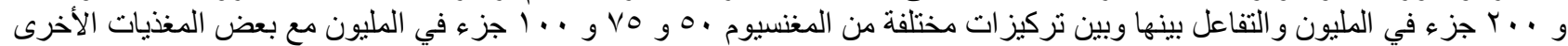

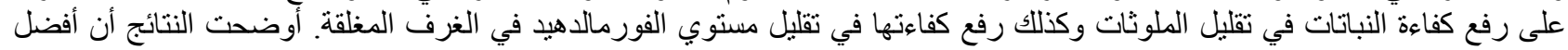

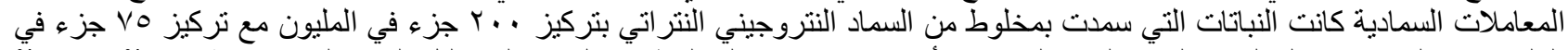

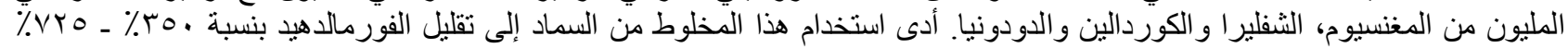

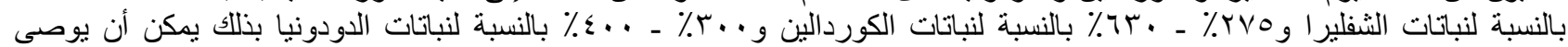

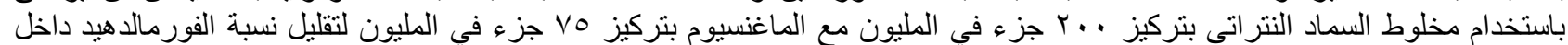

